\title{
PERAN MODEL FISIK DAN DIGITAL DALAM PERANCANGAN ARSITEKTUR
}

\author{
Albertus Prawata \\ Jurusan Teknik Arsitektur, Fakultas Sains dan Teknologi, Binus University \\ Jl. KH. Syahdan No. 9, Palmerah, Jakarta Barat 11480. \\ albertus_prawata@binus.ac.id
}

\begin{abstract}
An architectural design process is a process to design an architectural form involving a lot of aspects such as scale, spaces, functions, time and material. The ultimate objective is to create a complete design into a visual media to be presented and actualized in a physical form on a certain site or location. Physical and digital models are media that can be used to visualize an architecture design process from the conceptual step to the final design. Both media have important aspects in design process, as well as able to give design solutions. This article explains the use of physical and digital models with their own characteristics in architectural design process; observes any information from a physical model that can be used and transferred to a digital one; and provides some information about when the physical model and digital model should be used best during the architectural design process.
\end{abstract}

Keywords: physical model, digital model, architecture design process.

\begin{abstract}
ABSTRAK
Proses perancangan arsitektur merupakan suatu proses yang melibatkan berbagai macam aspek seperti skala, ruang, fungsi, waktu dan material untuk merancang suatu bentukan arsitektur. Tujuan akhirnya adalah untuk mewujudkan suatu rancangan yang menyeluruh ke dalam media visual untuk bisa dipresentasikan dan kemudian dapat diwujudkan dalam bentuk fisik pada suatu site/lokasi yang telah ditetapkan. Media fisik dan digital model merupakan media-media yang bisa digunakan untuk mevisualisasikan suatu proses dari tahap konseptual sampai dengan tahap akhir perancangan. Kedua media ini memiliki aspek-aspek penting dalam proses perancangan, dan keduanya dapat memberikan solusi-solusi desain yang dibutuhkan. Penulisan ini menjelaskan penggunaan model fisik dan digital beserta dengan karakteristiknya dalam proses perancangan arsitektur; melihat informasi apa saja yang bisa didapatkan dari model fisik yang kemudian dapat ditransfer ke digital model; serta dapat memberikan informasi kapan model fisik ataupun digital digunakan sebaiknya untuk membantu proses perancangan arsitektur.
\end{abstract}

Kata kunci: model fisik, model digital, proses perancangan arsitektur. 


\section{PENDAHULUAN}

Proses perancangan arsitektur di dalam studio, baik di dunia praktek maupun akademik merupakan suatu proses yang kompleks. Kemampuan seorang desainer akan diuji karena ia harus mampu mengerjakan berbagai macam tugas secara bersamaan. Pada proses perancangan, seorang desainer harus dapat menerima dan mencari semua informasi yang ia butuhkan, dan menghasilkan suatu hasil desain yang baik berdasarkan ide, teknik dan skill perancangan. Dengan kecepatan dan kemudahan-kemudahan yang ditawarkan media digital menjadikan penggunaan media fisik mengalami perubahan baik secara kualitas maupun kuantitas. Ketersediaan berbagai macam media digital (software) di pasaran saat ini, telah membentuk suatu perubahan besar bagi proses perancangan arsitektur. Dalam proses perancangan di dunia praktek dan akademik saat ini, penggunaan media digital semakin berkembang pesat. Faktor kecepatan dan efisiensi waktu untuk mempresentasikan suatu karya arsitektur merupakan salah satu faktor utama yang mempengaruhi penggunaan kedua media (fisik \& digital) ini. Kelebihan yang ditawarkan media digital memang terbukti memberikan keuntungan-keuntungan yang positif, tetapi pergantian karakteristik dari media fisik dan digital tidak mudah dijalankan. Para praktisi seperti, Ben Damon, James Glymph dan Frank Gehry menyampaikan bahwa model fisik memainkan peran penting dalam pengembangan desain (Mills, 2008). Kesadaran akan pentingnya media fisik dalam proses perancangan memberikan peluang-peluang baru dalam menghubungkan model fisik ke model digital dalam perancangan arsitektur.

\section{PEMBAHASAN}

\section{Model Fisik}

Maket arsitektur adalah sebuah tipe model yang berskala (juga disebut model fisik) - sebuah representasi dari struktur terbangun yang digunakan sebagai sebuah studi dalam desain arsitektur, atau untuk mengomukasikan ide desain kepada klien dan masyarakat luas. Maket pun memiliki jenis yang beragam, tergantung dari tujuan yang ingin diinformasikan oleh suatu maket. Maket yang dipergunakan dalam proses perancangan disebut dengan maket studi. Maket tersebut bertujuan untuk memunculkan ide-ide desain dan berfungsi sebagai wahana untuk menyempurnakan desain. Maketmaket ini dapat berupa maket singkat berkonstruksi kasar, hingga yang mendetail. Istilah maket studi mengisyaratkan bahwa maket-maket tersebut terbuka untuk diinvestigasi dan disempurnakan. (Mills, 2008)

Jenis dan tipe maket studi yang beragam dari maket sketsa sampai dengan maket presentasi, dapat memberikan suatu solusi-solusi desain. Terutama pada tahap awal perancangan arsitektur. Beberapa karakteristik model fisik berikut ini, merupakan aspek-aspek yang dapat dieksplorasi dalam suatu proses perancangan: (1) Model fisik bisa dibuat dari berbagai macam material; (2) Material; Ekspresi dan kualitas material model fisik mengkomunikasikan apa adanya. (void, berat, ringan, transparan); (3) Model fisik dapat diubah-ubah secara cepat; memvisualisasikan gubahan bentuk dan ruang secara cepat; (4) Model fisik merupakan proses yang terbuka, mengijinkan tingkat perubahan, kesempatan, dan kejadian yang tidak diduga (Cannaerts, 2009).

Maket studi merupakan suatu alat dalam proses perancangan, dan dapat memberikan suatu visualisasi bentuk yang cepat kepada desainer dan juga audience yang terlibat. Pada tahap konseptual desain, maket studi akan menjadi alat yang sangat kuat dalam proses kreatifitas dan juga apresiasi terhadap material. Interaksi yang terjadi dalam pembuatannya memberikan pengalaman yang tidak tergantikan, yaitu dialog antara konsep perancangan dan material yang digunakan, sehingga akan terjadi suatu proses seperti pengujian suatu keputusan desain. Beberapa contoh jenis maket studi yang 
bisa digunakan untuk tahap eksplorasi desain adalah maket sketsa, maket diagram, maket konsep, maket massa dan maket solid void.

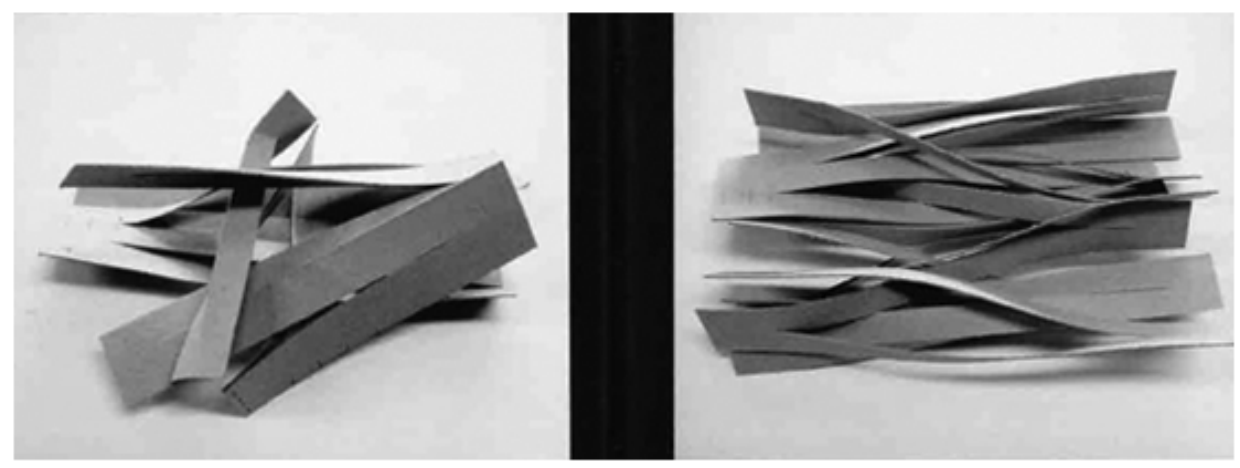

Gambar 1. Maket sketsa oleh Robert Bos. Sumber : Folding Architecture, p.100

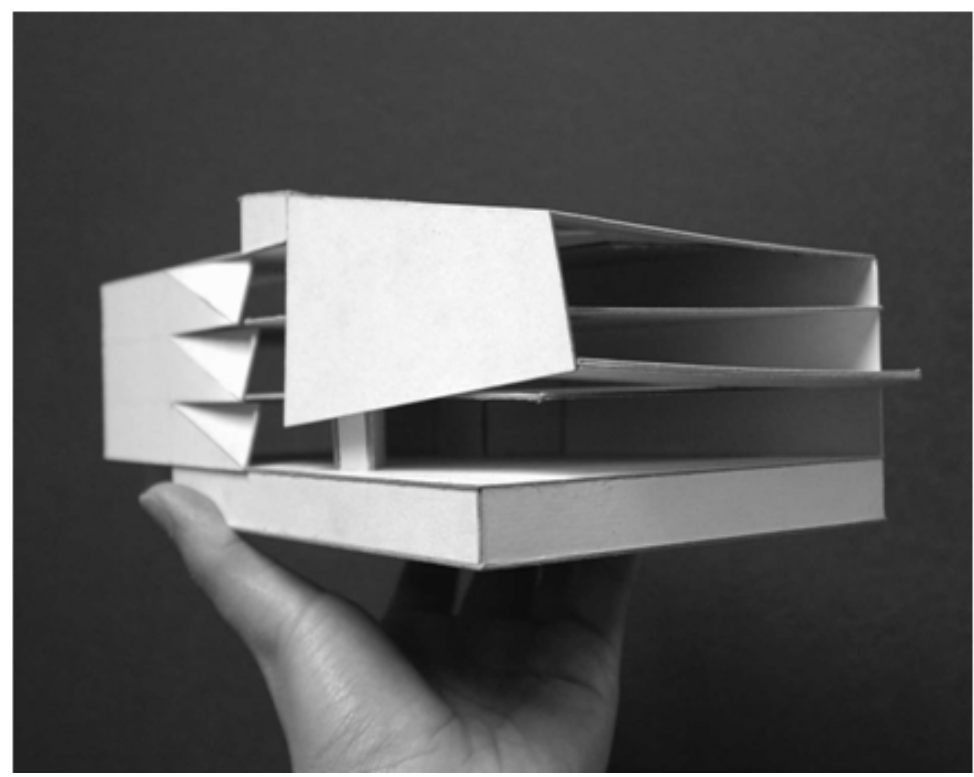

Gambar 2. Maket solid void oleh Albertus Prawata.

Sumber : Albertus Prawata

\section{Model Digital}

Perkembangan dunia digital saat ini telah membentuk dan melahirkan sebuah fenomena baru. Peralatan teknologi seperti komputer, laptop, dan smart phones selalu mengalami pembaruan untuk mendukung kebutuhan informasi-informasi yang ada. Dengan kebutuhan dan kemajuan informasi tersebut, dunia arsitektur juga terkena dampaknya. Dengan menggunakan software dan bantuan teknologi yang ada pada saat ini; eksplorasi desain dengan studi geometri, pemodelan tiga dimensi, penyimpanan data dan simulasi program sampai dengan rapid prototyping, memberikan suatu metode baru dalam proses perancangan arsitektur. Peran digital dalam proses perancangan arsitektur secara cepat telah memberikan pengaruh yang besar, berikut ini adalah karakterisitik yang dimiliki oleh model digital sebagai suatu alat dalam proses perancangan kontemporer dalam arsitektur: (1) Dengan 
ketersediaan berbagai macam aplikasi dan peralatan komputer saat ini, pengerjaan model digital dapat dilakukan semakin cepat dan produktif; (2) Model digital memberikan cara baru dalam proses perancangan; (3) Model digital menawarkan media baru bagi perancang untuk mempresentasikan desainnya kepada publik dengan lebih interaktif dan menarik.

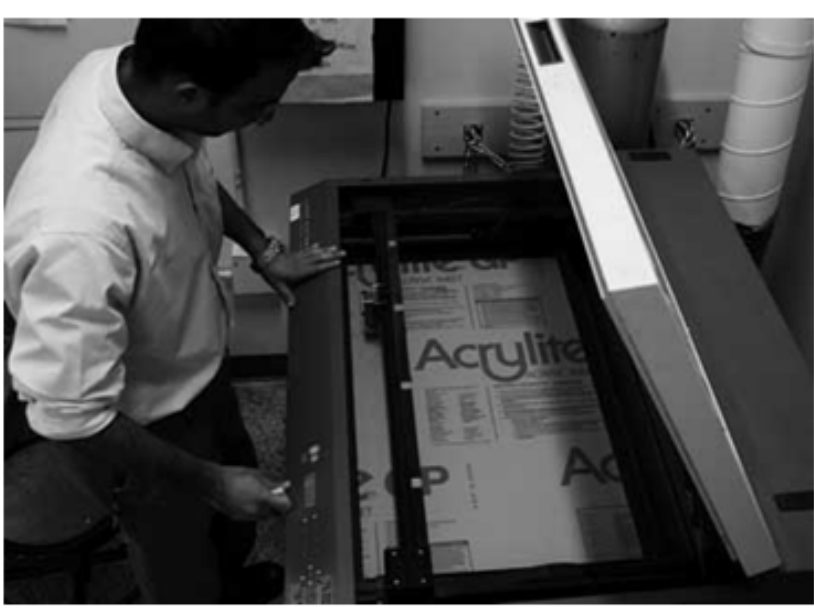

Gambar 3. Universal laser cutter.

Catatan: Mesin ini dapat digunakan untuk memotong hampir semua jenis material yang kemudian dapat dibentuk dan disusun, khususnya untuk bentuk-bentuk yang rumit dan kompleks (MIT, Rapid Prototyping Lab)

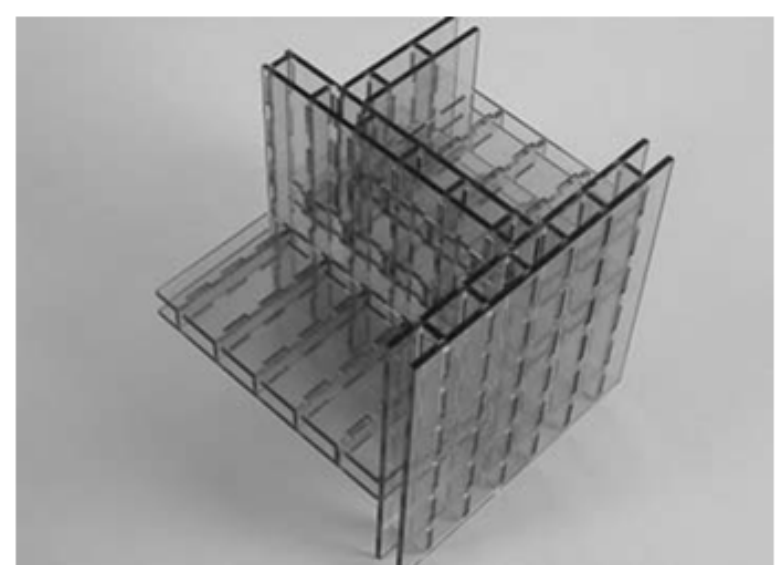

Gambar 4. Komposisi bentuk dari material akrilik yang telah dipotong menggunakan mesin laser cutter (MIT, Rapid Prototyping Lab).

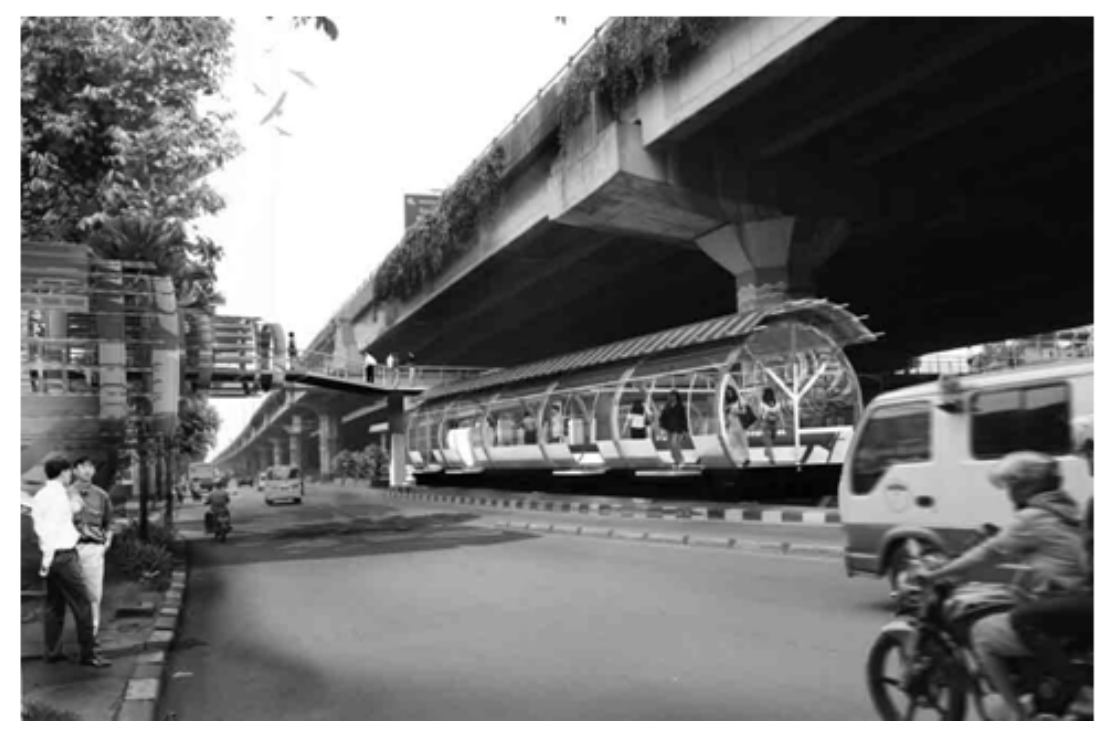

Gambar 5. Sunter/Kelapa Gading Smart Pedestrian HUB.

Catatan: Montage merupakan salah satu cara yang mudah dan cepat dilakukan untuk mengeksplorasi ide-ide desain (Albertus Prawata).

Teknologi telah mengijinkan dan membuka potensi-potensi yang bisa dikembangkan dalam proses perancangan arsitektur. Salah satunya adalah dengan mempresentasikan ide-ide pada suatu rancangan dalam bentuk model digital. Model digital dapat memberikan suatu presentasi yang inovatif dan menarik, dengan keunggulan aspek produktifitas pengerjaannya dibandingkan dengan model fisik. Dunia praktek pada saat ini melihat lebih jauh lagi dari drafting dan solusi visualisasi yang ditawarkan 
oleh teknologi digital. Hal ini merefleksikan keunikan dunia praktek saat ini, bahwa terbuka banyak peluang dalam ekplorasi desain dalam proses perancangan arsitektur (Bermudez \& Klinger, 2003).

\section{Pengembangan Model Fisik ke Digital}

Penggunaan media digital sebagai sarana komunikasi visual semakin meningkat sebagai bagian integral dalam proses merancang. Berbagai macam cara dan ekspansi dalam cara gambar, foto dan grafik digunakan bersama-sama untuk mendapatkan presentasi visual yang menarik (Mills, 2008). Salah satu pengembangan model fisik yang paling cepat dan relatif mudah adalah dengan mengambil foto model fisik yang kemudian dimodifikasi oleh salah satu software yang dapat memanipulasi foto tersebut. Beberapa informasi yang bisa kita dapatkan dari model fisik tersebut adalah: (1) Skala proporsi antar massa bangunan dan elemen elemen pembentuknya; (2) Material - struktur dan logika dalam pembuatan bangunan; (3) Karakter bangunan - ekspresi bangunan yang ditonjolkan; (4) Hubungan dengan lingkungan sekitar - keterkaitan bangunan dengan lingkungan sekitarnya.

Dari informasi-informasi tersebut, penggabungan dan kombinasi foto model fisik dan foto lainnya akan menghasilkan suatu visualisasi yang menarik, dan usaha ini tentunya jauh lebih mudah dan akan mengeluarkan biaya yang jauh lebih sedikit. Setelah mendapatkan suatu hasil manipulasi foto yang dihasilkan oleh penggabungan dan modifikasi gambar-gambar lainnya, pengerjaan manual pun masih tetap bisa dilakukan dengan mengembangkan gambar sketsa pada gambar tersebut.

Bert Bielefeld dan El Khouli (2007) menyatakan bahwa keberagaman dan kecepatan yang ditawarkan oleh media digital seperti computer aided drawing (CAD) sangat membantu dalam proses perancangan. Tetapi banyak dari arsitek dan perancang kesulitan merancang suatu bangunan dengan media ini karena tidak bisa digunakan secara intuitif. Untuk alasan tersebut, tahap pengerjaan dan pencarian ide-ide desain awal menggunakan media manual (model fisik, pensil, kertas) harus diselesaikan setelah didapatkan informasi-informasi yang cukup untuk dikembangkan ke tahap selanjutnya, yaitu pada media digital (model digital).

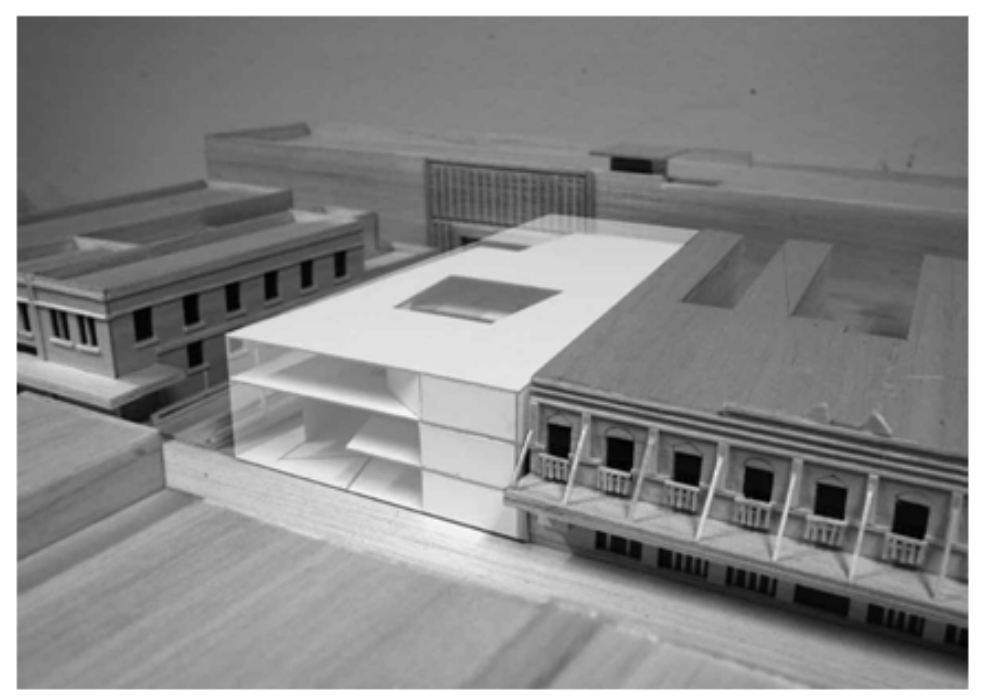

Gambar 6. Fiskal model yang dapat direkam dan dapat dipelajari dengan menambahkan sketsa-sketsa cepat untuk memperoleh bentuk dan desain yang diinginkan (Albertus Prawata). 


\section{PENUTUP}

Karakteristik yang dimiliki oleh model fisik dan digital menunjukkan keduanya merupakan suatu alat yang dapat digunakan dengan baik dalam mengeksplorasi solusi-solusi dalam proses perancangan. Efisiensi waktu dan produktifitas pengerjaan merupakan hal yang menjadi salah satu kendala dalam penerapan proses model fisik dan digital. Tetapi apabila kita dapat memetakan waktu dalam pengerjakan model fisik dan model digital, eksplorasi rancangan pun akan optimal. Kemampuan seorang perancang untuk menghasilkan model digital juga akan berpengaruh, sehingga diperlukan suatu interaksi terhadap material dan bentuk yang ingin ia hasilkan dengan mengeksplorasi model fisik sebelumnya. Hal ini tentunya dapat mempercepat proses pembuatan model digital tersebut. Untuk itu, kemampuan seorang perancang membuat model fisik dan mengeksplorasinya dengan media manual secara intuitif akan sangat membantu dengan cepat melanjutkan proses rancangan ke media digital. Dengan proses ini, model fisik dan model digital dapat memberikan solusi-solusi desain yang dibutuhkan dalam proses perancangan yang menyeluruh, sehingga dapat menghasilkan suatu rancangan yang baik.

\section{DAFTAR PUSTAKA}

Bermudez, J. \& Klinger, K. (2003). Digital Technology \& Architecture (ACADIA Whitepaper prepared for the NAAB).

Bielefeld, B. \& El Khouli, S. (2007). Design Ideas (1 $1^{\text {st }}$ ed.). Basel, Switzerland: Birkhäuser Publishing.

Cannaerts, Corneel. (2009). Teaching Physical \& Digital Modelling in Architecture. Proceedings of the Design Modelling Symposium. Berlin.

Mills, C.B. (2008). Merancang Dengan Maket (edisi kedua). Jakarta: Penerbit Erlangga.

MIT Department of Architecture. (2011). Rapid Prototyping Lab. Diakses 20 July 2011 dari http://web.mit.edu/arch/RPL/devices/laser_cutter.html 